\title{
Influenza and influenza vaccination in children
}

\section{Gripa şi vaccinarea antigripală la copii}

\author{
Viorel ALEXANDRESCU ${ }^{1,2}$, Alexandra VLAD², Dumitru MATEI ${ }^{3}$ \\ ${ }^{1}$ Institutul Naţional de Cercetare „Cantacuzino“ , Bucureşti, România \\ ${ }^{2}$ Facultatea de Medicină Generală, Universitatea „Titu Maiorescu“, Bucureşti, România \\ 3Universitatea de Medicină şi Farmacie „Carol Davila“, Bucureşti, România
}

\begin{abstract}
Influenza is a disease with a major impact on public health due to epidemic and pandemic developments, but also through severe forms of illness that frequently cause complications and deaths in people at high risk. But flu is also a disease that "costs" the sick individual and the community in which he lives and works. An important step in controlling influenza in children would be the vaccination of small children in the community, a measure that can be sustained by reducing spending on illness, complications and admissions.
\end{abstract}

Keywords: influenza, flu, epidemic, illness, high risk, vaccination, reducing illness spending

\section{REZUMAT}

Gripa este o boală cu impact major în sănătatea publică din cauza evoluțiilor epidemice și pandemice, dar și prin formele severe de îmbolnăviri care determină în mod frecvent complicații și decese la persoanele cu risc crescut. Dar gripa este și o boală care "costă" individul bolnav și comunitatea în care acesta trăiește și activează. Un pas important în controlul gripei la copii ar fi vaccinarea copiilor mici din colectivități, măsură care poate fi susținută prin reducerea cheltuielilor legate de îmbolnăviri, complicații și internări.

Cuvinte cheie: gripă, epidemie, îmbolnăvire, risc crescut, vaccinare, reducerea costurilor legate de îmbolnăviri

Gripa este o boală cu impact major în sănătatea publică din cauza evoluțiilor epidemice și pandemice, dar și prin formele severe de îmbolnăviri care determină în mod frecvent complicații și decese la persoanele cu risc crescut [persoane de orice vârstă cu boli cronice asociate, copiii mici sănătoși (0-2 ani), gravide și, nu în ultimul rând, persoanele cu imunodepresii dobîndite (postinfecțioase și induse medicamentos)].

Dar gripa este o boală care „costă“ individul bolnav și comunitatea în care acesta trăiește și activează. Costurile cazurilor individuale și comunitare (medicale și sociale) pot fi de ordinul milioanelor de dolari sau de euro în cazul epidemiilor de gripă.

În diagnosticul clinic al gripei la copii, medicii de familie trebuie să aibă în vedere unele particularități ale acestei boli la această categorie populațională.

Particularități:

- copiii mici cu gripă pot infecta alte persoane pe o perioadă mai mare de timp (>5 zile); 
- pe lângă simptomele adultului, copiii pot prezenta: +/- otită, vomă, +/- diaree;

- copiii cu gripă pot mima un sepsis bacterian cu febră mare și convulsii (6-20\% dintre cei internați);

- $\quad 4-10 \%$ dintre copiii cu gripă confirmată de laborator și cu internări de scurtă durată ( $\leq 2$ zile) au necesitat tratament în unități de terapie intensivă, iar $3 \%$ - ventilație mecanică;

- copiii mici prezintă relativ rar simptome tipice de gripă (febră și tuse);

- la copiii cu vârste cuprinse între 5 și 12 ani, valoarea predictivă pozitivă a febrei și tusei a fost de 71\%-83\%, comparativ cu $54 \%$ la copiii cu vârste < 5 ani;

- la copiii cu infecții gripale confirmate de laborator, doar $28 \%$ dintre cei internați și 17\% dintre cei tratați ca pacienți în ambulator au avut un diagnostic de gripă;

- testarea pentru gripă la toți copiii cu febră sau cu simptome de infecție acută a tractului respirator a arătat că $70 \%$ dintre copiii spitalizați cu vârsta < 6 luni cu gripă confirmată de laborator au prezentat febră și tuse, comparativ cu $91 \%$ din copiii internați cu vârste între 6 luni și 5 ani.

\section{EVOLUTJIE ŞI COMPLICAŢII}

\section{voca:}

Infecțiile cauzate de virusul gripal pot pro-

- pneumonie primară virală;

- exacerbarea afecțiunilor medicale bazale (de exemplu boli pulmonare sau cardiace);

- pneumonie bacteriană;

- sinuzită sau otită medie;

- coinfecții cu alți agenți patogeni virali sau bacterieni: RSV, pneumococ, Hemophilus influenzae, stafilococ-MRSA;

- mai puțin frecvente: encefalopatii, mielite transverse, miozite, pericardită, miocardită și sindromul Reye.

În ultimii ani există în unele țări o orientare a strategiilor de prevenire și control a gripei spre o acoperire vaccinală antigripală semnificativă la copii. Se cunoaște de către specialiști rolul copiilor de vârstă școlară și preșcolară (cei din instituții educaționale cu program scurt) în răspândirea gripei în familie și comunitate, dar controlul răspândirii trebuia susținut și de o evaluare a impactului medical și a aspectului cost-beneficiu ale unei imunizări de masă la aceste categorii populaționale. O serie de studii efectuate mai ales în SUA au evidențiat la copiii mici sănătoși un risc crescut de îmbolnăvire severă, complicații și deces care justifică în final vaccinarea în totalitate a copiilor cu vârste între 6 și 23 luni.

Specialiștii americani au mers mai departe și au recomandat vaccinarea tuturor copiilor până la 5 ani, deși riscul este mai scăzut între 3 și 5 ani, dar analiza cost-beneficiu este netă în favoarea unei imunizări în masă și la această grupă de vârstă. Din sezonul 2008/2009 s-a început în SUA o acțiune de creștere a acoperirii vaccinale la cei cu vârste de 6-18 ani, care se speră să ajungă în următorii ani la 100\%. Se realizează astfel al doilea deziderat al controlului optim al epidemiilor de gripă, și anume imunizarea persoanelor cu rolul cel mai important în răspândirea gripei, primul deziderat fiind acoperirea vaccinală semnificativă a persoanelor cu risc crescut. Dacă se ia în considerare că în SUA se vaccinează toți copiii cu vârste de 6 luni-5 ani, înseamnă că numărul total al vaccinărilor antigripale sezoniere în această țară ar putea ajunge la circa 150 milioane (circa $50 \%$ din populație) sau chiar mai mult dacă se va aplica ultima recomandare a ACIP (Advisory Committee on Immunisation Practices) de a se începe vaccinarea tuturor persoanelor cu vârste $\geq 6$ luni, ceea ce a devenit o țintă denumită de specialiști „vaccinarea universală“.

În România se pare că vaccinarea copiilor a trecut în planul al doilea sau chiar al treilea (aproape de zero), deși există și copii cu boli asociate care reprezintă un risc major de complicații și uneori de deces. Există o reticență a medicilor pediatri, dar mai ales a părinților, de a-și vaccina copiii mici (6 luni-5 ani) sănătoși, deși există la nivel național și internațional date care evidențiază rate mari de îmbolnăvire, complicații și deces care ar putea argumenta suficient această imunizare. Se înregistrează în timpul sezonului rece un număr mare de îmbolnăviri (posibile gripe) în rândul copiilor care frecventează grădinițele/creșele și nu puțini dintre acești copii fac complicații otice și pulmonare care necesită uneori spitalizare. Trebuie menționat că acești copii, mai ales școlari și preșcolari, au și un potențial crescut de răspîndire a gripei în familie, unde pot fi contacți cu persoane în vârstă, cu bolnavi cronici și uneori cu gravide, dar nu trebuie uitate și costurile directe și indirecte care decurg din managementul îmbolnăvirii acestora.

Credem că un pas important în controlul gripei la copii ar fi vaccinarea copiilor mici din colectivități, care poate fi susținută prin reducerea cheltuielilor legate de îmbolnăviri, complicații și 
internări. Ar fi de dorit o promovare activă din partea medicilor de familie și pediatri de a recomanda vaccinarea antigripală a copiilor mici de la prima infecție respiratorie apărută în sezon (după vindecarea acesteia) fie în ambulatoriu, fie la externarea din spital. Fiind la început, o asemenea abordare va necesită un efort deosebit, dar, în același context, copiii mici cu risc crescut (boli cronice etc.) trebuie vaccinați în totalitate. Un al doilea pas în creșterea vaccinărilor la copii ar putea fi compensarea vaccinului gripal prin Casa Națională de Asigurări de Sănătate, pentru că ea suportă costurile tratamentului cazurilor din ambulatoriu și internate în spital, dar și plata, unde este cazul, a alocațiilor pentru îngrijirea copiilor bolnavi.

Un fapt este sigur, o gripă costă mai mult decât un vaccin și această afirmație este susținută de foarte multe studii, inclusiv de un studiu efectuat în România de către Centrul Național de Gripă în anul 2015, care arată următoarele costuri:

I. Costurile profilaxiei și tratamentului gripei

a. Vaccin gripal $=20,75$ lei $=4,64$ euro

b. Terapie antivirală ( 7 zile)

- adult $=107,38$ lei $(24,07$ euro $)$

- copil = 76,7 ron (17,19 euro)

II. Costurile tratamentului cazurilor individuale de gripă pe forme clinice și grupe de vârstă (2015) (Tabelul 1)

Medicii de familie și pediatrii vor avea însă și un alt obstacol foarte greu de depășit și anume reticența sau chiar opoziția unor părinți care încă consideră că vaccinul este reactogen (chiar periculos), ineficient și foarte scump.
Credem că autoritatea și experiența medicilor practicieni vor convinge mai mult decât orice studiu că gripa este o boală severă și că vaccinarea antigripală este cea mai bună metodă de diminuare a complicațiilor, internărilor și deceselor provocate de epidemiile de gripă.

Pentru a ilustra importanța pe care o acordă vaccinării copiilor, vom prezenta recomandările din septembrie 2017 ale American Academy of Pediatrics, apărute în revista Pediatrics.

September 2017

From the American Academy of Pediatrics Policy Statement

\section{COMMITTEE ON INFECTIOUS DISEASES RECOMANDĂRI PENTRU PREVENIREA ȘI CONTROLUL GRIPEI LA COPII ÎN SEZONUL 2017-2018}

Această declarație actualizează recomandările pentru utilizarea de rutină a vaccinului gripal sezonier și a medicamentelor antivirale pentru prevenirea și tratamentul gripei la copii. Academia Americană de Pediatrie recomandă vaccinarea anuală a gripei sezoniere pentru toți cei cu vârsta de 6 luni și peste, inclusiv copii și adolescenți. Repere importante pentru sezonul 2017-2018:

1. Imunizarea anuală globală a gripei este indicată fie cu un vaccin trivalent, fie cu patru valențe (fără preferință), inactivat;

2. Tulpina vaccinală gripală A (H1N1) 20172018 diferă de cea conținută în vaccinurile sezoniere 2016-2017. Tulpinile vaccinale gripale A (H3N2) și tulpinile de vaccin gripal B incluse în vaccinurile trivalente și quadrivalente 2017-

TABELUL 1. Costurile cazurilor de gripă

\begin{tabular}{|l|c|c|c|}
\hline Forma clinică & Adult & Persoane în vârstă & Copil \\
\hline Gripă uşoară 2-4 zile (3 zile) & $\begin{array}{c}52,09 \text { RON } \\
(11,65 €)\end{array}$ & $\begin{array}{c}53,15 \text { RON } \\
(11,89 €)\end{array}$ & $\begin{array}{c}35,50 \mathrm{RON} \\
(7,49 €)\end{array}$ \\
\hline Gripă medie 4-6 zile (5 zile) & $56,73 \mathrm{RON}$ & $56,73 \mathrm{RON}$ & $43,47 \mathrm{RON}$ \\
& $(12,69 €)$ & $(12,69 €)$ & $(9,72 €)$ \\
& $343,23 \mathrm{RON} *$ & & \\
& $(76,78 €)$ & & $53,04 \mathrm{RON}$ \\
& $58,14 \mathrm{RON}$ & $59,14 \mathrm{RON}$ & $(11,86 €)$ \\
Gripă medie cu complicații & $(13,23 €)$ & $(13,23 €)$ & \\
6-8 zile (7 zile) & $460,24 \mathrm{RON} * *$ & & \\
& $(102,96 €)$ & & $1102,4 \mathrm{RON}$ \\
& $1169,94 \mathrm{RON}$ & $1167,05 \mathrm{RON}$ & $(246,6 €)$ \\
\hline Gripă severă cu complicații & $(261,73 €)$ & $(261,08 €)$ & \\
şi internare în spital 8-12 zile & $1742,94 \mathrm{RON} * * *$ & & \\
(10 zile) & $(181,91 €)$ & & \\
& \multicolumn{3}{|c}{} \\
\hline
\end{tabular}

*concediu medical 5 zile

** concediu medical 7 zile

$* * *$ concediu medical 10 zile 
2018 sunt aceleași cu cele din vaccinurile sezoniere 2016-2017:

a. vaccinul trivalent conține un virus asemănător cu A / Michigan / 45/2015 (H1N1) pdm09, un virus asemănător cu $A$ / Hong Kong / 4801/2014 (H3N2) și un virus B / Brisbane / Victoria lineage); și

b. vaccinul quadrivalent conține un virus suplimentar B (virus B / Phuket / 3073/2013 [B / Yamagata lineage]);

3. Toți copiii cu alergie la ouă, indiferent de severitate, pot primi un vaccin gripal fără precauții suplimentare, în afara celor recomandate pentru orice vaccin;
4. Tot personalul din domeniul sănătății trebuie să primească anual un vaccin gripal sezonier, un pas esențial în prevenirea gripei și reducerea infecțiilor asociate cu gripa, deoarece personalul medical îngrijește adesea persoanele cu risc crescut de complicații legate de gripă;

5. Pediatrii \& medicii de familie ar trebui să încerce să identifice cu promptitudine copiii suspectați de infecție gripală pentru inițierea în timp util a tratamentului antiviral, atunci când este indicat, pentru a reduce morbiditatea și mortalitatea. Cele mai bune rezultate sunt observate când infecțiile gripale sunt tratate în 48 de ore de la debutul simptomelor.

Conflict of interest: none declared Financial support: none declared

\section{BIBLIOGRAFIE}

1. MMWR - Prevention and Control of Seasonal Influenza with Vaccines: Recommendations of the Advisory Committee on Immunization Practices United States, 2017-18 Influenza Season; Recommendations and Reports / August 25, 2017 / 66(2);1-20

2. Cost-effectiveness and socio-economic aspects of childhood influenza vaccination - Nichol, Kristin L. Vaccine; Kidlington 29.43 (Oct 6, 2011): 7554-7558.
3. Plotkin's Vaccines. 7th Edition: Elsevier; Published Date: 6th June 2017

4. WHO: Weekly epidemiological record; 3 November 2012, 87th year, Vaccines against influenza WHO position paper -

5. CDC - Atlanta: Seasonal Influenza (Flu) Vaccination and \& Preventable Disease (www.cdc.gov)

6. ECDC: Seasonal influenza vaccination in Europe; technical report, 20 Jul 2017, (www. ecdc.eu)
7. Red Book, 30th Edition (2015); Report of the Committee on Infectious Diseases, 30th Edition; Edited by David W. Kimberlin, MD, FAAP, Michael T. Brady, MD, FAAP, Mary Ann Jackson, MD, FAAP and Sarah S. Long, MD, FAAP

8. MS - CNSCBT: Metodologia de supraveghere şi control a gripei în sezonul 2016/2017 (www.ms.ro \& www.cnscbt.ro) 